\title{
Resonanties in de pulmonologie
}

Citation for published version (APA):

Wouters, E. F. M. (1993). Resonanties in de pulmonologie. Datawyse / Universitaire Pers Maastricht. https://doi.org/10.26481/spe.19930122ew

Document status and date:

Published: 22/01/1993

DOI:

10.26481/spe.19930122ew

Document Version:

Publisher's PDF, also known as Version of record

\section{Please check the document version of this publication:}

- A submitted manuscript is the version of the article upon submission and before peer-review. There can be important differences between the submitted version and the official published version of record.

People interested in the research are advised to contact the author for the final version of the publication, or visit the DOI to the publisher's website.

- The final author version and the galley proof are versions of the publication after peer review.

- The final published version features the final layout of the paper including the volume, issue and page numbers.

Link to publication

\footnotetext{
General rights rights.

- You may freely distribute the URL identifying the publication in the public portal. please follow below link for the End User Agreement:

www.umlib.nl/taverne-license

Take down policy

If you believe that this document breaches copyright please contact us at:

repository@maastrichtuniversity.nl

providing details and we will investigate your claim.
}

Copyright and moral rights for the publications made accessible in the public portal are retained by the authors and/or other copyright owners and it is a condition of accessing publications that users recognise and abide by the legal requirements associated with these

- Users may download and print one copy of any publication from the public portal for the purpose of private study or research.

- You may not further distribute the material or use it for any profit-making activity or commercial gain

If the publication is distributed under the terms of Article $25 \mathrm{fa}$ of the Dutch Copyright Act, indicated by the "Taverne" license above, 


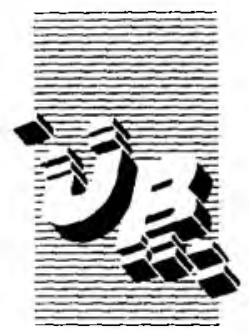

De uilleentermijn verstrijki op:

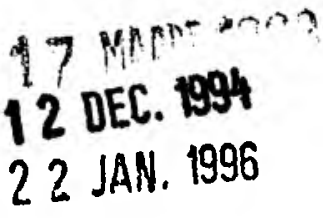

24 FEB. 9997

17 JUN 9997

16 SEP, $\{997$

Rijksuniversileil Limburg

Posibus 616

- 6 OKT. 9999

6200 MD Maastricht

Gelieve deze publicatie tijdig te retourneren of (telefonisch) verlenging van de uitleentermijn aan te vragen. 


\section{Resonanties in de pulmonologie}

\section{REDE}

uitgesproken bij de aanvaarding van het ambt van hoogleraar Pulmonologie aan de Rijksuniversiteit Limburg op vrijdag 22 januari 1993

door

EMIEL FRANS MARIA WOUTERS

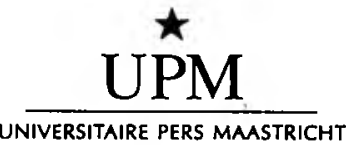




$$
\begin{aligned}
& \text { ppw } 10183263 X \\
& \text { 年 }
\end{aligned}
$$

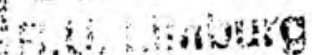

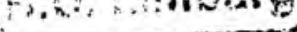

ISBN 9052780633

DATAWYSE | Universitaire Pers Maastricht 
Mijnheer de Rector Magnificus, Leden van het College van Bestuur der Rijksuniversiteit Limburg, Dames en Heren Hoogleraren en leden van de Wetenschappelijke Staf, Dames en Heren Studenten, en voorts Gij allen, die door Uw aanwezigheid blijk geeft van Uw belangstelling,

Zeer gewaardeerde toehoorders,

In de oorspronkelijke betekenis kan het Latijnse woord "inaugurare" worden omschreven als het raadplegen van de auguren. Door waarneming en verklaring van bepaalde voortekenen stelden auguren vast of de goden een voorgenomen daad goed- of afkeurden. Een inauguratie kan worden beschouwd als het uitspreken van een waarneming en verklaring van bepaalde voortekenen op het betreffend vakgebied door de nieuwe hoogleraar ten overstaan van de universitaire gemeenschap.

Raadpleging van de auspicia door de magistraat of de universitaire gemeenschap gebeurt vanuit een toekomstverwachting. Een inauguratie zal derhalve een beschrijving moeten omvatten met betrekking tot te verwachten ontwikkelingen op het betreffend vakgebied. Volgens de regeling der inaugurele redes van de Rijksuniversiteit Limburg stelt de nieuwe hoogleraar zich op deze wijze voor aan de universitaire gemeenschap, waarbij wordt toegevoegd dat de inhoud van de rede zo eenvoudig mogelijk en voor leken begrijpelijk moet zijn. Op deze wijze geformuleerd, wordt van de augur tevens verwacht dat hij ingaat op een verondersteld essentieel aspect van een harmonische maatschappelijke evolutie, met name de vertaling van de wetenschap en kennis voor de samenleving, die hierbij uitgenodigd wordt deel te nemen aan een ontdekkingstocht op het vakgebied van de longziekten.

Inauguratie aldus gedefinieerd schept problemen voor de moderne augur. Waarneming en verklaring van bepaalde feiten kan worden beschouwd als uitdrukking van een empirische benadering van de werkelijkheid. Deze belangrijke kennistheoretische stroming zag in de allesomvattende ervaring van de mens de 
toegang tot de kennis van de werkelijkheid, waarbij alle theorieën die niet waren gebaseerd op een methodisch gezuiverde zintuiglijke waarneming werden verworpen. Kenmerkend is dat de gehele werkelijkheid als een in principe te begrijpen werkelijkheid werd beschouwd en dat een uitverkoren groep de waarheid in pacht had ${ }^{1}$.

Een kenmerk van een huidig augur is de nuancering van denken: hij openbaart geen waarheid, maar is zich bewust dat zijn kennis niet meer is dan de beste interpretatie van het geheel van alle bekende feiten en dat deze kennis in het subversieve graafwerk van het wetenschappelijk onderzoek steeds opnieuw in twijfel zal worden getrokken. De augur, zoals vandaag gehuld in het imponerende gewaad van de wetenschappelijk deskundige, blijft een feilbaar wezen, niet noodzakelijk omdat hij als mens faalt, maar omdat het zo moeilijk is de werkelijkheid te omvatten. In een feilbare opvatting van de menselijke kennis is onze onwetendheid, vergeleken met onze kennis bijna onmetelijk ${ }^{1}$. In de mate dat het wetenschappelijk onderzoek uitdrukking is van de geconcentreerde aandacht van de mens voor de buiten hem gelegen werkelijkheid, is de onderzoeker bovendien ondergeschikt aan het bestudeerde object ${ }^{2}$. Door zich te omhullen met het symbolisch gewaad van de toga, geeft de moderne augur uitdrukking aan zijn bereidheid zich te onderwerpen aan een werkelijkheid die het eigen "ik" overstijgt. Ondanks de snelle ontwikkelingen geldt de beperktheid in kennis zeker voor het vakgebied der geneeskunde.

Als praktisch wetenschapper wordt de medicus dagelijks geconfronteerd met de beperktheid in handelen en behandelen. De geneesheer daarentegen, die geneeskunst bedrijft, tracht mogelijk steunend op een verwevenheid tussen charitas en praxis empirische antwoorden te formuleren op zoveel mogelijk hulpvragen.

Niet alleen de verandering in werkelijkheidsbegrip, maar ook de mogelijkheid tot waarneming zelf van de exponentieel versnellende groei aan wetenschappelijke informatie dwingt tot moderatie. 
Een assimilatiebreuk ten gevolge van de snelheid en omvang van huidig beschikbare informatiestromen is heden niet alleen een maatschappelijk probleem, maar doet zich ook voor op afgelijnde vakgebieden.

Wordt de wereldgeschiedenis van 4,5 miljard jaar herleid tot een tijdschaal die loopt van de geboorte van Christus tot vandaag, stond enkele uren geleden de augur nog de vlucht en gekrijs van de vogels waar te nemen, en waren Pythagoras, Plato en Aristoteles slechts acht uur dood. Twee uur geleden vond Gutenberg de boekdrukkunst uit en één uur geleden bracht o.m. Galilei elementen aan van de algemene gravitatiewet van Newton ${ }^{3}$. Het recente eerherstel van Galilei die inging tegen een openbaringsuitspraak van de Kerk kan op deze wijze nog als voortvarend worden beschouwd. Werd door de Medische Academie van Erlangen op het einde van de vorige eeuw nog beweerd dat de mens boven een snelheid van $75 \mathrm{~km}$ per uur hersenletsel zou oplopen, dan is door onder meer de verplaatsingsnelheid van moderne auguren deze hypothese in voldoende mate gefalsifiëerd.

Dezelfde snelheid en ontwikkeling kan worden vastgesteld op het vakgebied van de geneeskunde en de verschillende deelspecialismen. Hierbij kan worden verwezen naar de snelheid waarmee de medische technologie zich in een tijdsspanne van enkele tientallen jaren heeft meester gemaakt van het leven. In het vakgebied der longziekten betekende het beschikbaar komen van röntgenapparatuur in het begin van deze eeuw nog een belangrijke bijdrage in de opsporing van tuberculose; heden wordt de longarts geconfronteerd met computertomografie, nucleaire magnetische resonantie en andere gesofisticeerde beeldvormende technieken. De omvang aan beschikbare informatie leidt tot suggesties in wetenschappelijke tijdschriften om onderscheid aan te brengen tussen wetenschappelijke publikaties, die bestemd zijn voor zogenaamd praktizerende artsen en deze die bestemd zijn voor "hen die hun kunst eerder doceren dan bedrijven". Het klinkt als de vraag naar 
de augur, die vanuit een ivoren toren houvast aanreikt in de draaikolk van wetenschappelijke informatie.

Deze vraag naar een houvast wordt mede versterkt door een exponentieel toenemende complexiteit van de werkelijkheid. Op deze wijze wordt de moderne augur een tolk in de wetenschappelijke toren van Babylon. Door de multidisciplinaire probleemstelling van het merendeel der medische problemen, zal de augur, aangesteld op een medisch vakgebied, derhalve niet alleen de medische taal moeten spreken, maar ook de taal moeten verstaan van de fysiologie, epidemiologie, biochemie, farmacologie, immunologie, moleculaire biologie en zo vele anderen. Ook de Romeinse augur lette niet uitsluitend op de vlucht of geschreeuw van de vogels; donder, bliksem, het vreten van heilige kippen waren even belangrijke fenomenen bij het houden van het auspicium.

\section{Tuberculose 110 jaar na Koch}

De ontwikkeling van het vakgebied longziekten is onverbrekelijk verbonden met de geschiedenis der tuberculose. Inderdaad, heden kan de ernst van deze aandoening, zeker in Westerse landen, vanuit een historisch perspectief worden beschreven. Ook voor Limburg en meer bepaald voor Maastricht was de witte dood of witte pest een waar schrikbeeld. Na Overijssel had immers Limburg in het begin van deze eeuw het hoogste sterftecijfer aan tuberculose. Dit was vooral het gevolg van het hoge sterftecijfer in Maastricht, dat in 1918 dubbel zo hoog was als gemiddeld in Nederland ${ }^{4}$. De betekenis van deze ziekte in de eerste helft van deze eeuw moge ook blijken uit de woorden van Vestdijk: 'wanneer leven niet denkbaar is zonder tuberculose, dan kan tuberculose voor het leven op zijn minst symbolisch in de plaats treden'. Het opzetten van een netwerk van consultatiebureaus en de recentere ontwikkeling van moderne tuberculostatica hebben bijgedragen tot een dramatische vermindering in de incidentie van tuberculose in Nederland. 
Een speciale ontwikkeling van de tuberculose was de oprichting van sanatoria. Ondanks de vaststelling in navolging van Bronkhorst dat in deze instellingen lichamelijke rust één van de belangrijkste peilers vormde van de tuberculosebehandeling, hebben de sanatoria vele schrijvers stof geleverd tot inspiratie. Hierbij wordt vooral gedacht aan "Der Zauberberg" (1924) van Thomas Mann, maar ook sanatorium Hornerheide gold als een literaire broedplaats. De ellende werd, zoals uitgedrukt door Berghuis, omgevormd tot een sublieme wraakneming: 'letterkunde uit de sputumkweek, literatuur uit de röntgenkamer ${ }^{5}$. Mogelijk werd hierdoor bijgedragen aan het scheppen van het belangrijk geachte klimaat van aangename geestelijke ontspanning of zoals uitgedrukt in de oratie op 6 december 1948 uitgesproken door Bronkhorst als eerste hoogleraar in de longziekten in Nederland tot het 'psychisch moment bij de behandeling van longtuberculose'.

Voor de wereldbevolking is 110 jaar na de ontdekking van de tuberkelbacil door Koch tuberculose nog steeds een zeer belangrijk gezondheidsprobleem. De Wereldgezondheidorganisatie schat dat vandaag meer dan 1,5 miljard mensen geïnfecteerd zijn met de tuberkelbacil van wie 20 miljoen een actieve ziekte vertonen. Elk jaar worden 8 miljoen nieuwe gevallen van tuberculose gemeld en sterven 3 miljoen mensen ten gevolge van deze ziekte. In de ontwikkelingslanden is tuberculose hiermee de belangrijkste behandelbare doodsoorzaak binnen de economisch actieve bevolkingsgroep ${ }^{6}$. In schril contrast hiermee is de vaststelling dat indien de dalende trend van de jongste decennia zich doorzet de tuberculose-infectieprevalentie in Nederland in het jaar 2025 zal zijn gedaald tot minder dan één per honderd inwoners en dat de incidentie van sputumpositieve longtuberculose minder dan één per miljoen zal bedragen, overeenkomend met de conventionele grens van de eradicatie van de tuberculose 7 . Toenemende immigratie van personen vanuit landen met hoge tuberculoseprevalentie, toename van HIV-infecties, verslechtering van de medische en/of sociaal economische omstandigheden in marginale groepen 
en toenemende vergrijzing van de bevolking dwingen echter tot blijvende waakzaamheid.

Op 10 december 1949 werd door het bestuur van de Vereeniging van Nederlandsche Tuberculose Artsen een naamsverandering in Vereniging van Artsen voor Longziekten en Tuberculose goedgekeurd. Registratie van longartsen vindt heden nog steeds plaats als "arts voor longziekten en tuberculose". De huidige infectie-incidentie van tuberculose in Nederland maakt dat deze ziekte, indien al behandeld door de longarts, slechts een beperkt onderdeel vormt van de heden door de longarts behandelde infectieuze longaandoeningen, niet in overeenstemming met de historisch bepaalde vermelding van deze ziekte in de naamgeving van het specialisme.

\section{The greatest international killer}

Een belangrijke ontwikkeling in het vakgebied Longziekten is de toenemende prevalentie van longkanker of van de "Mala Metallorum", zoals kanker van de long voor het eerst in 1531 door Paracelsus werd beschreven. In 1952 vond in Leuven nog een symposium plaats over de "endemiologie" van longkanker om zoals geformuleerd in de doelstellingen van het congres variaties in verdeling en gedrag van de tumor over verschillende etnologische groepen in verschillende plaatsen te bestuderen in relatie met lokale factoren met als doel bij te dragen aan het voorkomen van bronchuscarcinoom ${ }^{8}$. Aan het begin van de 21 e eeuw heeft longkanker epidemische proporties aangenomen.

Longkanker is veruit de meest frequent voorkomende maligniteit bij mannen en in de Verenigde Staten verdringt longkanker bij vrouwen borstkanker als frequentst voorkomende doodsoorzaak ten gevolge van maligne processen ${ }^{9}$. Noch scalpel, noch cobalt-en andere stralen, noch cytostatica dragen heden in belangrijke mate bij tot genezing van deze aandoening. 
Eén belangrijke factor is hiervoor aan te duiden: het roken van sigaretten. Roken is in de Westerse landen de belangrijkste te vermijden oorzaak van overlijden. Op dit ogenblik sterven jaarlijks 2,5 miljoen mensen ten gevolge van het roken van sigaretten. De Wereldgezondheidorganisatie schat de mortaliteit t.g.v. roken in 2025 op 10 miljoen doden per jaar ${ }^{10}$. Economische belangen maken het mogelijk dat het gordijn van tabaksrook, een mengsel van honderden chemisch reactieve bestanddelen, meerdere tientallen carcinogene stoffen en het sterk verslavende nicotine wereldwijd nog niet is opgetrokken. Dagelijks wordt deze belangrijke doodsoorzaak verkocht in een verpakking van glitter en goede gezondheid. Doelgerichte marketing blijkt uit de benadering van vrouwelijke slachtoffers met de slogan: "Keep thin, slim and light" ${ }^{\prime 1}$. Door de tabaksindustrie in Nederland werd in 1990 ongeveer 200.000 .000 guldens uitgegeven aan reclame voor tabaksartikelen. Gezien de ontwikkelingen in rookgedrag de afgelopen jaren kan nu reeds met teleurstelling worden geconcludeerd dat de door de overheid gewenste reductie van het percentage rokers tot ongeveer $20 \%$ onder mannen en $15 \%$ onder vrouwen in het jaar 2000 een illusie is ${ }^{12}$. Beroep doen op de eigen verantwoordelijkheid van het individu, medicalisering door roken te beschouwen als een ziekte op zich zijn even zovele rectificaties van rookgedrag als het hanteren van het causaliteitsprincipe door de tabaksindustrie, m.n. dat het mechanisme waardoor sigaretterook kanker veroorzaakt tot op heden onopgehelderd bleef. De dubbelzinnige rol tot voor kort van overheden kan worden geillustreerd met het advies aan Britse regeringsleden gegeven in het begin van de jaren ' 60 , waarin werd gesteld dat "zij konden zeggen wat $\mathrm{zij}$ wilden over roken en gezondheid, zolang zij maar rookten, wanneer zij iets zegden"13. Medici en andere gezondheidszorgmedewerkers moeten zich bewust zijn van hun voorbeeldfunctie om te komen tot een rookvrije samenleving en hebben een belangrijke rol in het ondersteunen van anti-rook gedrag. 
Chronische long- en luchtwegaandoeningen: een maatschappelijke uitdaging

Een belangrijk aandachtsgebied in het vakgebied longziekten wordt gevormd door de groep aandoeningen, die in de Griekse oudheid \%) werden genoemd. Met het doel personen met overeenkomstige verschijnselen overal en ten allen tijde op dezelfde wijze te groeperen, is in Nederland de term CARA - chronische aspecifieke respiratoire aandoeningen - ontwikkeld als omschrijvende definitie van een bepaald symptomencomplex ${ }^{14}$. Aanvalsgewijze optredende of voortdurend aanwezige kortademigheid, hoesten en opgeven van sputum behoorden tot deze CARA-verschijnselen. In het rapport van de commissie ter bestudering van de nomenclatuur van asthmatische ziekten, verschenen in 1966, werd gesteld dat het een operationele definitie betreft en geen diagnose in de gebruikelijke zin van het woord ${ }^{14}$. CARA is heden niet alleen een uiting van ongelijksoortige ziektemanifestaties ${ }^{15}$, maar ook van ongelijksoortige ziekten. Behoudens in manifestatie van klinische verschijnselen, zijn o.m. astma en emfyseem ontwikkeld tot duidelijk verschillende ziektebeelden met specifieke pathogenetische en pathologische kenmerken. In toenemende mate is tevens de multifactorialiteit van zogenaamd gemeenschappelijke symptomen duidelijk geworden.

Waar destijds werd gesteld dat de diagnosen "astma", "bronchitis" en "emfyseem" ongeschikt zijn voor gebruik in wetenschappelijk onderzoek ${ }^{15}$, kan heden worden geconcludeerd dat het begrip "CARA" als operationele definitie ontoereikend is voor wetenschappelijke doelstellingen tenzij voor gebruik in epidemiologisch onderzoek. Waar ook in laatstgenoemde onderzoeksrichting nadere specificatie van respiratoire symptomen noodzakelijk is, geldt dit zeker voor de klinische praktijk, waar analyse van de multifactoriële determinatie van een bepaald symptomencomplex de basis vormt van een individueel gedifferentieerde behandeling. 
Chronische long- en luchtwegaandoeningen worden niet langer beschouwd als een te bagatelliseren volksziekte, maar vormen heden een belangrijk maatschappij- en gezondheidszorgprobleem. De jaarlijkse maatschappelijke direct patiëntgebonden en indirecte kosten van deze groep chronische ziekten kunnen heden op 1,5 miljard guldens worden geraamd ${ }^{10,17}$. Chronische long- en luchtwegaandoeningen vormen de derde doodsoorzaak in Nederland. Uitsluitend rekening houdend met de te verwachten demografische veranderingen in de bevolking wordt een stijging verwacht van bijna $17 \%$ van het aantal bekende patiënten met chronische long-en luchtwegaandoeningen in het volgend decennium. Andere scenario's resulteren in een toename van deze patiëntengroep met $75 \%$ in het jaar $2005^{17}$. Bij het begin van de eenentwintigste eeuw zullen chronische long- en luchtwegaandoeningen dezelfde plaats innemen in de dagelijkse praktijk van de longarts als tuberculose bij het begin van de twintigste eeuw.

Huidige rapportage van een mondiale toename in incidentie en prevalentie van chronische luchtwegklachten vooral bij schoolgaande kinderen is slechts in beperkte mate betrokken bij hogergenoemde inschattingen van het gesteld gezondheidszorgprobleem ${ }^{18}$. Het optreden van deze epidemiologische veranderingen over een relatief korte tijdsperiode, gekoppeld aan huidige inzichten m.b.t. het optreden van bronchiale hyperreactiviteit als basiskenmerk van deze aandoeningen, legt een toenemende nadruk in de pathogenese op exogene factoren. Exogene factoren in de micro-omgeving van de woning bieden heden slechts een beperkte en soms falsifieerbare verklaring voor het gesteld probleem. Voldoende inzicht ontbreekt in de bijdrage van langdurige blootstelling aan huidig genormeerde luchtverontreiniging. Dosimetrisch inzicht, o.a. rekening houdend met de complexe anatomische structuur van de menselijke long, voor specifieke gebieden of celstructuren in de long zelf ontbreekt. Inzicht is nodig met betrekking tot de genetische en moleculaire basis van specifieke cellulaire processen ten gevolge van luchtverontreiniging zowel als acute reactie als in de ontwikkeling van chronische permanente 
veranderingen in de long ${ }^{19,20}$. Alhoewel de mens uitgerust is om te overleven in een vijandige omgeving en hiervoor over een uitgebreide reservecapaciteit beschikt, vraagt de huidige ontwikkeling een gestructureerde aanpak, rekening houdend met de complexiteit van het gesteld probleem en moet ontkenning of onderschatting vaak berustend op simplificatie van de probleemstelling worden vermeden.

Opvattingen worden bovendien gemoduleerd door de dynamiek van het wetenschappelijk onderzoek. Dit moge blijken uit de gewijzigde opvatting m.b.t. de gevolgen van expositie aan mijnstof. Waar in 1954 door de Medische Commissie Longaandoeningen Mijnwerkers het standpunt werd ingenomen dat de diagnose antracosilicose slechts kan worden gesteld bij duidelijk omschreven radiologische afwijkingen en dat emfyseem en chronische bronchitis niet in causaal verband kunnen worden gebracht met mijnstofinademing, blijkt heden op basis van epidemiologische gegevens en inzicht in de cellulaire gevolgen van mijnstofinhalatie, dat deze expositie niet alleen tot de bovenvermelde chronische diffuse interstitiële longaandoeningen kan leiden, maar ook tot optreden van chronische bronchitis en emfyseem, al dan niet voorkomend met luchtwegobstructie ${ }^{21}$. Expositie tijdens beroepsmatige blootstelling vraagt ook in de toekomst speciale aandacht: heden staan chronische long- en luchtwegaandoeningen klaar om de klassieke pneumoconiosen als beroepsmatige longaandoening nummer één op te volgen ${ }^{22}$.

De multifactorialiteit van bepaalde klinische symptomen kan worden geillustreerd met huidige pathofysiologische inzichten met betrekking tot patiënten met chronisch obstructief longlijden. Door ontbreken van vooraf vastgestelde veranderingen in bepaalde longfunctieparameters wordt een belangrijke groep van deze patiënten beschouwd als hebbende een irreversibel obstructief longlijden. Speciale aandacht richt zich heden bij deze patiënten op de functionele toestand van de ademhalingsspieren, onze ademhalingspomp met een dagelijks debiet schommelend tussen 
de 10.000 en 20.000 liters lucht. Voedingsdepletie ten gevolge van een verstoring van de energiebalans door een verhoogd energieverbruik is een frequent voorkomend probleem bij deze patiëntengroep en draagt in belangrijke mate bij tot dysfunctioneren van skelet- en ademhalingsmusculatuur. Nieuwe behandelingsvormen kunnen op deze wijze worden ontwikkeld. In de mate immers dat voeding gericht is op een herstellen van een verstoorde energiebalans, is, in afwezigheid van hyperkatabolie, voeding in dit geval te beschouwen als een noodzakelijk therapeuticum. Indien respiratie bovendien niet alleen beperkt blijft tot uitwisseling van $\mathrm{O}_{2}$ en $\mathrm{CO}_{2}$ met de omgeving, maar ook tot verbruik van $\mathrm{O}_{2}$ en produktie van $\mathrm{CO}_{2}$ door individuele cellen, dient de longarts cellulaire ademhaling m.n. het oxidatief metabolisme te betrekken bij de benadering van pathologische processen. In de huidige black box benadering van gaswisseling die reikt tot de alveolocapillaire membraan word hiermede nog onvoldoende rekening gehouden.

Zo vormt ook longrevalidatie een uitbreiding van zorg aan deze patiëntengroep. Longrevalidatie kan worden gedefinieerd als een vorm van medisch handelen door een multidisciplinair team van hulpverleners, waardoor beperkingen en handicaps op somatisch, psychisch en relationeel gebied, die de patiënt ten gevolge van deze aandoening ondervindt, dusdanig worden beïnvloed dat de patiënt optimaal kan functioneren in het dagelijks leven, gegeven diens mogelijkheden en beperkingen. Op deze wijze richt deze behandelingsvorm zich op een verbetering van de kwaliteit van leven, niet louter gedefinieerd als een verbetering van de kwaliteit van het bestaan, maar als een verbetering van de kwaliteit van mens-zijn voor de individuele patiënt ${ }^{23}$. Voor vele patiënten betekent longrevalidatie inderdaad "een weg terug uit het donker, de mist en de desoriëntatie; een weg terug naar een leven dat zinvol kan zijn en dat de moeite waard is om te worden geleefd ${ }^{24}$.

Bovengeschetste ontwikkelingen veronderstellen een reorganisatie van zorg en zorgvernieuwing met als doel de huidig bereikte standaard in zorgverlening in Nederland te behouden en verder 
te ontwikkelen. Reorganisatie van zorg veronderstelt geen verdeling van patiëntengroepen over de verschillende lijnen in de gezondheidszorg met de vaak hiermee gepaard gaande taakafbakening, maar integratie van de verschillende zorglijnen. Belangrijk is hierbij de inschakeling van de preventieve sector m.n. de jeugdgezondheidszorg om door vroegtijdige herkenning van klachten bij te dragen aan een verbetering of opheffing van de onderliggende aandoening. De aandacht van de tweede lijn moet zijn gericht op volwaardige diagnostiek, rekening houdend met de huidige pathofysiologische inzichten. De vooraanstaande rol door Nederland vervuld m.b.t. de klinische fysiologie van de ademhaling heeft bijgedragen tot een uniek netwerk van goed uitgeruste longfunctielaboratoria met uitvoering van onderzoekingen volgens internationale standaarden door hiervoor speciaal opgeleid personeel. Huidige tendensen tot simplificatie van diagnostiek doen afbreuk aan de bereikte inzichten in complexiteit van pathologische veranderingen bij deze aandoeningen met onderwaardering van de ernst ervan als mogelijk gevolg. Als arts voor longziekten in dit geval chronische long- en luchtwegaandoeningen is de longarts in zijn tweedelijnsfunctie opgeleid voor aanbieden van een geïntegreerde en integrale diagnostiek aan de eerstelijn. Uitgaande van verkregen diagnosestelling zal een geïndividualiseerd zorgplan moeten worden opgesteld dat verder reikt dan louter farmacologische beïnvloeding volgens vastgestelde standaarden. Bij uitvoering van dit behandelplan speelt de huisarts een centrale rol. Speciale aandacht verdient hierbij de patiëntengroep met chronisch obstructief longlijden. Rekening houdend met gelijke prevalenties in de totale bevolking wijzen huidige statistieken op een sterke afna me van deze patiëntengroep in de praktijkvoering zowel van de huisarts als van de longarts ${ }^{25}$.

Zorgvernieuwing veronderstelt in een beleid dat speciale aandacht wil schenken aan Chronisch Zieken anticiperende besluitvorming ten aanzien van opgestelde toekomstscenario's gezondheidszorg. Rapportage van een totale toename van medische consumptie ten gevolge van chronische long- en luchtweg- 
aandoeningen maakt een reële uitbreiding van macro-allocatieve middelen noodzakelijk, des te meer indien zoals verwoord in de nota Chronisch Ziekenbeleid ${ }^{26}$ het uitgesproken beleidsvoornemen is de heersende achterstandspositie van chronische zieken te verbeteren. Immers, in de mate dat keuzes moeten worden gemaakt in de gezondheidszorg is deze een politieke aangelegenheid geworden: een zorg van de polis of de gemeenschap als zodanig. $\mathrm{Na} 25$ eeuwen dreigt omwille van gezondheidseconomische motieven hiermee de Hippocratische traditie te worden doorbroken. Immers, in de eed van Hippocrates, zoals in 1948 opgesteld door de Wereldgezondheidorganisatie, is opgenomen dat de gezondheid van "mijn" patiënt "mijn" eerste bekommernis zal zijn. Keuzes maken in de gezondheidszorg betekent voor de patiënt eveneens een beperking in het sinds de Franse revolutie erkend natuurlijk recht op gezondheidszorg. Beperking van middelen zonder nemen van keuzes in de gezondheidszorg zal leiden tot een toenemend spanningsveld tussen zorgvraag en te bieden zorgaanbod. Opvang van geschetste ontwikkelingen m.b.t. patiënten met chronische long-en luchtwegaandoeningen veronderstelt in toenemende mate het brengen van de zorgen naar de mensen en naar hun leefmilieu in plaats van de mensen naar het verzorgingsmilieu.

\section{Wetenschappelijk onderzoek en opleiding}

Vertrekkend van onze beperktheid in kennis ten aanzien van de werkelijkheid is wetenschappelijk onderzoek onlosmakelijk verbonden met elke activiteit van de mens gericht op de buiten hem gelegen werkelijkheid. Deze beperktheid in kennis geldt zeker in belangrijke mate in het vakgebied der longziekten zowel met betrekking tot oncologische problematiek als met betrekking tot chronische long- en luchtwegproblemen. Met betrekking tot laatstgenoemde groep aandoeningen heeft een werkgroep van de Raad voor Gezondheidsonderzoek recent twee hoofdlijnen van onderzoek aanbevolen, te weten "de oudere patiënt met chronisch obstructief longlijden" en het "jonge kind met astma" 27 . In de mate 
dat een onderzoeker heden alle mogelijkheden van de experimentele methode aanwendt om te komen tot een grondige kennis van biologische wetmatigheden of van bepaalde therapieën, kan klinisch onderzoek worden beschouwd als een anticipatie op de toekomstige stand van de medische wetenschap: de ethos van de onderzoeker en van de medicus als hulpverlener zijn in dit geval niet tegengesteld. Derhalve is wetenschappelijk onderzoek een essentieel onderdeel in de invulling van de functie van een academisch ziekenhuis in het algemeen en een academische afdeling in het bijzonder ${ }^{28}$.

Als praktische wetenschap wordt de ontwikkeling van de geneeskunde verder in belangrijke mate bepaald door ontwikkelingen in de diverse basiswetenschappen. De dynamiek van een matrixorganisatie biedt zeker ten aanzien van klinisch wetenschappelijk onderzoek de mogelijkheid tot fundamentele en efficiënte ondersteuning van geformuleerde vraagstellingen vanuit basiswetenschappen. Oriëntatie van het wetenschappelijk onderzoek in een beperkt aantal themata of zwaartepunten dwingt verder de onderzoeker tot permanente reflectie m.b.t. te formuleren vraagstellingen. De vakgroep Pulmonologie heeft de voorbije jaren een basis gelegd voor uitbouw van het wetenschappelijk onderzoek door participatie aan de themata "Voeding en Toxicologie", "Groei en differentiatie" en "Perinatalogie" mede door integratie van het onderzoek op het gebied van de klinische fysiologie van de ademhaling onder leiding van collega Luijendijk. Deze groei naar volwassen-en volwaardigheid van de jongste academische longafdeling in Nederland is alleen mogelijk door verdere ondersteuning van structurele uitbouw van de vakgroep. De ernst van de bovengeschetste maatschappelijke problematiek en de aansluiting van belangrijke pulmonale probleemstellingen bij de facultaire thematiek en het academisch zwaartepuntenplan onderstrepen deze visie. Verheugend is de vaststelling dat onderzoek met betrekking tot longen en luchtwegen binnen de Rijksuniversiteit Limburg tevens onderwerp is geworden van meerdere vakgroepen.Speciale vermelding verdient hierbij het onderzoek naar long- 
en luchtwegaandoeningen in relatie tot milieu en werkomgeving, waarvan in het rapport van de Raad voor Gezondheidsonderzoek wordt vermeld dat betreffend onderzoek in Nederland nog onvoldoende is ontwikkeld ${ }^{27}$.

Heden heb ik slechts een beperkt beeld geschetst van de veelzijdige taakstelling van de longarts. In een tweedelijnsfunctie m.n. als arts voor chronische long- en luchtwegaandoeningen richt zijn aandacht zich zowel op de mens met zijn ziekte als in zijn ziek-zijn; als orgaanspecialist wordt verder een hoge techniciteit in handelen verondersteld.

Deskundigheid op betreffend vakgebied kan heden niet louter berusten op empirie, maar veronderstelt het verwerven van toetsbare theoretische kennis van een vooraf vastgesteld opleidingsprogramma, rekening houdend met een op te stellen functieomschrijving en gewenste profilering van de longarts in de eenentwintigste eeuw. Kennis reikt hịerbij verder dan de vrijblijvende definitie, geformuleerd door de Specialisten Registratie Commissie, m.n. het zich op de hoogte stellen van bestaande diagnostische en therapeutische mogelijkheden, hun indicaties en contra-indicaties en het leren interpreteren van uitkomsten van onderzoek ${ }^{28}$. Het verwerven van maatschappelijke erkenning van deskundigheid kan parafraserend op het Sartriaanse credo niet langer worden overgelaten aan wat een deskundige in opleiding individueel uitmaakt. Behoud van deskundigheid veronderstelt verdere uitwerking van een kwaliteitsbewakingssysteem met aanbieden van een gestructureerd en gecoördineerd postgraduaat onderwijsprogramma.

\section{Dankwoord}

Aan het einde gekomen van deze oratie, waarin ik uitdrukking heb gegeven van mijn resonanties op het vakgebied longziekten, wil ik gebruik maken van de gelegenheid een dankwoord uit te spreken. 
Het College van Bestuur en het Bestuur van de Faculteit der Geneeskunde van de Rijksuniversiteit Limburg dank ik voor het geschonken vertrouwen mij als hoogleraar Pulmonologie te benoemen. Voor vervulling van deze taak zal ik mij volledig inzetten.

De Raad van Bestuur en de Raad van Toezicht van het Academisch Ziekenhuis Maastricht dank ik voor mijn aanstelling als afdelingshoofd van de afdeling Longziekten. Uitbouw van de academische functie van de afdeling Longziekten beschouw ik als een belangrijk te realiseren doel.

Het bereiken van deze positie is slechts mogelijk geweest door de steun en scholing, die ik van velen mocht ontvangen.

Het uitspreken van postume woorden van dank wekt steeds droefenis. Hooggeleerde Greve, beste Leo, jouw afwezigheid op deze dag beschouw ik als een groot gemis. Jouw levensfilosofie indachtig, kan het kruisen en scheiden van onze levensloop geen toeval zijn geweest. Uitbouw van de afdeling en vakgroep, waarvan jij de grondslagen hebt gelegd, beschouw ik als een groot voorrecht.

Hooggeleerde Visser, beste Ben, mijn belangstelling voor de longfysiologie werd door jou in belangrijke mate aangescherpt. Jij hebt mij in resonantie gebracht voor bestudering van ruissignalen en andere harmonische trillingen.

Zeergeleerde Ten Velde, Beste Guul, jij hebt mij mede ingevoerd in de kliniek der longziekten. De opgedane ervaring van jouw benadering van pulmonale oncologie versterkt mijn overtuiging dat de uitbouw van de pulmonale oncologie bij jou in veilige handen is.

Hooggeleerde Luijendijk, beste Sybrand, mede samen met jou de volgende jaren invulling geven aan het wetenschappelijk onderzoek van de vakgroep Pulmonologie beschouw ik als een belangrijke uitdaging. 
Heren leden van de staf van de afdeling Longziekten, en dames en heren medewerkers van de vakgroep Pulmonologie, ik ben jullie dankbaar voor het vertrouwen en de steun gedurende het voorbije jaar. Steunend op hechte samenwerking hebben wij allen een gemeenschappelijke taak: de uitbouw van de afdeling Longziekten en de vakgroep Pulmonologie.

Dames en heren studenten, $\mathrm{U}$ vormt de rechtvaardiging voor onze aanwezigheid aan de universiteit. De voorbije decade heb ik ervaren dat door integratie van theorie en praktijk en door intensieve vaardigheidstraining het probleemgestuurd onderwijs de mogelijkheden biedt te anticiperen op de in de toekomst te leveren gezondheidszorg. De uitspraak van de Efesische filosoof Heraclites blijft in het Maastrichtse onderwijssysteem nog steeds actueel: "vorming betekent niet het vullen van een emmer, maar het onsteken van een vuur". Het vuur voor longziekten brandend houden doorheen het curriculum beschouw ik als een belangrijke taak.

Vader en moeder, jullie hebben mij de ruimte geboden en gelaten mijn weg te zoeken. Ik ben jullie daar zeer dankbaar voor.

Tenslotte ben ik dankbaar dat ik deze rede heb mogen uitspreken in de aanwezigheid van mijn familieleden, mijn kinderen Kirsten, Elke en Birgit, en vooral van mijn vrouw. Rita, ik ben je dankbaar voor je onvoorwaardelijke steun gedurende vele jaren.

Ik heb gezegd. 


\section{Geraadpleegde literatuur}

1. van Vucht Tijssen L., van Reijen W.: Kennis en werkelijkheid: benaderingen. 1991 Coutinho BV.

2. Schotsmans P.: En de mens schiep de mens. 1992 DNB/Uitgeverij Pelckmans, Kapellen.

3. De Meester P.: Mens en techniek. 1991 Uitgeverij Lannoo nv, Tielt.

4. Philips R.: Gezondheidszorg in Limburg. Groei en acceptatie van de gezondheidsvoorzieningen 1850-1940. 1980 Van Gorcum, Assen.

5. Haneveld G.T.: In medische handen: 100 jaar geneeskunst. 1986 Uitgeverij SUN, Nijmegen.

6. Murray J.F., Enarson D.A.: World lung health: a concept that should become a reality. Am. Rev. Respir. Dis. 1992; 146: 818822.

7. Bleiker M.A., Styblo K.: De toekomst van de tuberculose als infectieziekte in Europa. Tijdschr. voor Geneesk. 1989; 45: 14491453.

8. Cancer of the Lung (endemiology). 1954, I.S.A.D., Louvain.

9. Feldman A.R., Kessler M.P.H.L., Myers M.H., Naughton M.D.: The prevalence of cancer: estimates based on the Connecticut Tumor Registry. New Eng. J. Med. 1986; 315(22): 1394-1398.

10. Soffer A.: The greatest international killer. Chest 1992; 101(1): 1-2. 
11. Davis R.M.: Current trends in cigarette advertising and marketing. New Eng. J. Med. 1987; 316(12): 725-732.

12. Stuurgroep Toekomstscenario's Gezondheidszorg: Kanker Signaleringsrapport 3 1992. 1992 STG, Rijswijk.

13. Taylor P.: The smoke ring: tobacco, money and multinational politics. 1985 Sphere Books Ltd., London.

14. Gezondheidsraad (Nationale commissie voor gezondheidsstatistieken): Rapport inzake standaardisatie van begrippen en methoden met betrekking tot Chronische Aspecifieke Respiratoire Aandoeningen (CARA). 1966.

15. Lende van der R., Jansen-Koster E.J., Knijpstra S., Meinesz A.F., Wever A.M.J., Orie N.G.M.: Definitie van CARA in epidemiologie en preventie. Ned. T. Geneesk. 1975; 119(50): 1975-1987.

16. Mölken van M.P.M.H.: Rapport; CARA in cijfers: verslag van een pilot-studie. 1989, Maastricht.

17. Stuurgroep Toekomstscenario's Gezondheidszorg: Chronische ziekten in het jaar 2005. Deel 2. Scenario's over CARA 1990-2005. 1990 STG, Rijswijk.

18. Gergen P.J., Weiss K.B.: The increasing problem of asthma in the United States. Am. Rev. Respir. Dis. 1992; 146: 823-824.

19. Crapo J., Miller F.J., Mossman B., Pryor W.A., Kiley J.P.: Environmental Lung Diseases; Relationship between acute inflammatory responses to air pollutants and chronic lung disease. Am. Rev. Respir. Dis. 1992; 145: 1506-1512.

20. Godlee F., Walker A.: Health and the environment. 1992 British Medical Journal. 
21. Gezondheidsraad: Commissie Silicosediagnostiek: Rapport 'Diagnostiek van silicose'. 1992 Gezondheidsraad, nr. 17, Den Haag.

22. Cullen M.R., Cherniack M.G., Rosenstock L.: Occupational medicine. New Eng. J. Med. 1990; 322(9): 594-601.

23. Musschenga A.W.: Kwaliteit van Leven: criterium voor medisch handelen? 1987 Uitgeverij Ambo bv, Baarn.

24. Sporken P.: De weg terug. 1991 Uitgeverij Ambo bv, Baarn.

25. Diagnose Informatie en Medische Statistiek (DIMS): CARA. 1992 IMS Nederland BV, Den Haag.

26. Nota Chronisch-ziekenbeleid, Chronische patiënten niet buiten spel, Tweede kamer der Staten-Generaal, vergaderjaar 1990-1991, 22025, nr. 1.

27. Raad voor Gezondheidsonderzoek (RGO): Adviesnota 'Onderzoek op het gebied van Chronische Aspecifieke Respiratoire Aandoeningen (CARA). 1991.

28. Koninklijke Nederlandse Maatschappij tot bevordering der geneeskunst: Erkenning en registratie van medische specialisten. 1981. 